\title{
WARNA LOKAL JAWA NOVEL PASAR KARYA KUNTOWIJOYO DAN SUMBANGSIHNYA TERHADAP PENGEMBANGAN KARAKTER PESERTA DIDIK
}

\author{
JAVANESE LOCAL COLOR OF PASAR NOVEL BY KUNTOWIJOYO AND ITS \\ CONTRIBUTION TO THE CHARACTER DEVELOPMENT OF STUDENTS
}

Ivana Septia Rahaya, Slamet Subiyantoro, Budhi Setiawan

Program Pascasarjana, Universitas Sebelas Maret

Jalan Ir. Sutami, No. 36 A, Surakarta, Jawa Tengah, Indonesia 57126

ivanaseptiarahaya@student.uns.ac.id

(Naskah diterima tanggal 8 Juli 2020, direvisi terakhir tanggal 8 Februari 2021, dan disetujui tanggal 20 Mei 2021)

DOI: https:/ / doi.org/10.26499/wdprw.v49i1.601

\begin{abstract}
The purpose of this research is to describe and explain Javanese local color in Pasar novel by Kuntowijoyo and its contribution to the character development of students. This research is a descriptive qualitative with a literary anthropology approach. Data collection techniques using note-taking techniques, while data analysis techniques are content analysis techniques. The results of this research indicate that Pasar novel contains Javanese local colors such as (a) the setting in Gemolong District; (b) a religious system that believes in the existence of God but still maintains their religious culture; (c) social systems and social organizations that describe the social status of Javanese people; (d) the knowledge system of Javanese priyayi figures; (e) language; and (f) Javanese philosophy which is used as a principle of society's life. The local color in Pasar novel has an important role to add to cultural knowledge and positive values, so if that novel is used as literary teaching materials it will help students develop their characters for the better.
\end{abstract}

Keywords: globalization; local color; Javenese; character education

\begin{abstract}
Abstrak
Tujuan penelitian ini adalah mendeskripsikan warna lokal Jawa novel Pasar karya Kuntowijoyo serta sumbangsihnya terhadap pengembangan karakter peserta didik. Penelitian ini merupakan penelitian deskriptif kualitatif dengan pendekatan antropologi sastra. Teknik pengumpulan data menggunakan teknik baca catat, sedangkan teknik analisis data ialah teknik analisis isi (content analysis). Hasil penelitian ini menunjukkan bahwa novel Pasar mengandung warna lokal Jawa seperti (a) latar tempat di Kecamatan Gemolong; (b) sistem religi yang mempercayai adanya Tuhan, tetapi tetap mempertahankan budaya religinya; (c) sistem kemasyarakatan dan organisasi sosial yang menggambarkan status sosial masyarakat Jawa; (d) sistem pengetahuan tokoh priyayi Jawa; (e) bahasa; serta (f) falsafah Jawa yang digunakan sebagai prinsip hidup masyarakat. Warna lokal dalam novel Pasar memiliki peran penting untuk menambah pengetahuan budaya dan nilai-nilai positif sehingga apabila novel tersebut digunakan sebagai bahan ajar sastra, akan membantu peserta didik mengembangkan karakternya menjadi lebih baik.
\end{abstract}

Kata-kata Kunci: globalisasi; warna lokal; Jawa; pendidikan karakter 


\section{Pendahuluan}

Menambah pengetahuan lokal dan melaksanakan pendidikan karakter saat ini sangat diperlukan mengingat banyak masyarakat Indonesia yang sudah terseret arus negatif globalisasi. Melalui penelitiannya, Agustin (2011) mengungkapkan bahwa degradasi moral terjadi akibat berkembangnya teknologi internet di era globalisasi yang disalahgunakan oleh kalangan pelajar. Sebesar $61,1 \%$ remaja usia $14-24$ tahun sudah terkena dampak negatif dari facebook yang menyebabkan ketidakpedulian terhadap lingkungannya, kurangnya sosialisasi dengan lingkungan, berkurangnya waktu belajar, dan lain sebagainya.

Globalisasi memiliki lima pilar penting, yaitu abstraksi, futurisme, individualisme, liberalisme, dan sekularisme (Rippin, 1993: 12). Pilar-pilar tersebut tentu saja bertolak belakang dengan budaya Indonesia yang mengedepankan kebersamaan. Apalagi, masyarakat Indonesia dikenal sebagai masyarakat yang religius. Segala sesuatu yang berkiblat pada modernitas yang biasanya dilakukan oleh bangsa barat dianggap menjadi sebuah prestise sehingga banyak masyarakat Indonesia memilih untuk melupakan budayanya dan berpaling pada segala hal yang dinilai lebih modern.

Salah satu solusi yang dapat dilakukan untuk menyelesaikan masalah di atas ialah pengenalan budaya dan internalisasi nilainilai karakter bagi masyarakat Indonesia, khususnya para pelajar yang akan menjadi penerus bangsa. Tanpa pengetahuan budaya, masyarakat akan mengalami disorientasi yang menyebabkan kehidupan sosial bahkan kehidupan pribadi menjadi kacau (Triyanto 2014:35). Pendidikan karakter juga harus dilakukan di dalam lingkup keluarga, sekolah, maupun masyarakat untuk membentuk perilaku positif, sehingga degradasi moral dan kekerasan dapat diminimalisir (Sebo, dkk, 2017: 35).

Pengenalan budaya dan pendidikan karakter tersebut dapat dilakukan melalui pembelajaran sastra, terutama novel yang di dalamnya mengandung warna lokal. Warna lokal dalam suatu karya sastra dapat diartikan sebagai suatu corak khas bernuansa kedaerahan yang mampu mendorong pembaca untuk menikmati karya tersebut sekaligus mendapatkan ciri khas suatu daerah atau lingkungan yang diceritakan. Karya sastra yang mengangkat warna lokal tersebut memiliki pengaruh besar terhadap pengetahuan budaya dan pembentukan karakter pembacanya. Pembaca dengan latar belakang budaya yang berbeda akan terbantu untuk mengenal berbagai tradisi, kesenian, dan prinsip hidup masyarakat budaya lain, sehingga mampu mendorong majunya pengetahuan budaya lokal serta sikap saling menghargai. Setiap budaya memiliki tradisi dan aturan berupa norma-norma tertentu yang secara tidak langsung mampu menginternalisasikan nilai-nilai positif serta membentuk karakter pembaca karya sastra tersebut.

Pengarang merupakan anggota suatu kelompok masyarakat yang tidak dapat memi-sahkan diri dari latar belakang budayanya. Oleh karena itu, latar belakang yang dimiliki oleh pengarang mampu menjadi unsur ekstrinsik yang memengaruhi terciptanya karya sastra. Suatu kelompok masyarakat memiliki ciri khas yang mampu membedakannya dengan kelompok masyarakat lain. Hal tersebut dapat berupa sikap, kepercayaan, tradisi, dan pandangan hidup. Kekhasan inilah yang mampu menjadi warna tersendiri pada karya sastra yang dihasilkan oleh pengarang.

Hartono (2015), dalam penelitiannya, mengungkapkan bahwa pada tahun 19701995 sastrawan Indonesia ramai mengangkat 
budaya lokal daerah asalnya masingmasing. Bahkan, pada tahun 1920-an budaya lokal merupakan tanda dimulainya awal kelahiran novel Indonesia. Beberapa contoh novel-novel tersebut yaitu Pengakuan Pariyem (1981) karya Linus Suryadi A. G, Ronggeng Dukuh Paruk (1982) karya Ahmad Tohari, Canting (1986) karya Arswendo, dan Tirai Menurun (1993) karya NH. Dini. Melalui penelitian tersebut juga diketahui bahwa novel-novel pada tahun 1970-1995 mengangkat budaya lokal yang terdiri dari latar tempat, kesenian, kepercayaan, status sosial masyarakat, dan penggunaan bahasa.

Berdasarkan uraian tentang pentingnya pengetahuan budaya dan pendidikan religius di atas, peneliti tertarik untuk menganalisis salah satu novel karya Kuntowijoyo yang berjudul Pasar. Melalui novel tersebut, Kuntowijoyo menceritakan proses pewarisan budaya dan nilai-nilai budaya yang dimiliki oleh masyarakat Jawa dari berbagai golongan, antara lain priayi, wong cilik, birokrat, dan pedagang kapitalis. Banyaknya warna lokal dan nilai-nilai positif di dalam novel tersebut membuat peneliti tertarik untuk menganalisisnya. Adanya penelitian ini diharapkan dapat membantu pembaca lebih mengenal budaya lokal Jawa, baik dari kebiasaan, prinsip hidup, kesenian, dan unsur-unsur budaya lain, sehingga pembaca akan menambah pengetahuan budaya, mengambil nilai-nilai positif, serta pada akhirnya akan mendorong perkembangan karakter yang lebih baik lagi.

Pendekatan yang digunakan dalam penelitian ini ialah pendekatakan antropologi sastra. Antropologi sastra merupakan bidang ilmu yang digunakan untuk menganalisis dan memahami terhadap suatu karya sastra dalam kaitannya dengan budaya suatu kelompok masyarakat (Ratna 2011: 152). Terdapat beberapa faktor yang memengaruhi hubungan antropologi dan sastra,salah satunya adalah bahwa kedua ilmu tersebut mempelajari realitas hidup manusia. Antropologi membahas fakta hidup manusia dalam suatu kelompok masyarakat yang berbudaya, sedangkan sastra mampu menggambarkan realitas kehidupan manusia yang sudah didesain sedemikian rupa oleh pengarang (Endraswara, 2013: 9). Berdasarkan teori tersebut, dapat disimpulkan bahwa antropologi sastra merupakan suatu pendekatan yang digunakan untuk menganalisis suatu karya sastra dan hubungannya dengan segala aspek kebudayaan yang ada di dalam karya sastra tersebut.

Penelitian serupa pernah dilakukan sebelumnya. Annisa dan Indiatmoko (2017) menganalisis novel Perempuan Jogja karya Achmad Munif. Melalui penelitian tersebut dapat diketahui bahwa unsur intrinsik novel Perempuan Jogja seperti tema, penokohan, alur, latar, dan sudut pandangnya sangat merepresentasikan budaya masyarakat Yogyakarta. Selain itu, hasil penelitian tersebut juga mengungkapkan bahwa Achmad Munif selaku penulis novel mencerminkan sistem penikahan adat Jawa yang masih kental dengan perjodohan, pernikahan antarkelas sosial, ritual pernikahan, sampai gambaran kehidupan pernikahan budaya Jawa.

Penelitian lain dilakukan oleh Hikmasari dan Sahayu, (2019)dengan fokus pembahasan pada unsur-unsur material dalam novel Entrok karya Okky Madasari. Penelitian tersebut membuktikan bahwa novel Entrok menggambarkan berbagai hasil budaya masyarakat Jawa, seperti makanan, bangunan, pakaian, kendaraan, peralatan sehari-hari, sampai alat kesenian.

Dibandingkan dengan penelitian sebelumnya, penelitian ini memiliki kebaharuan. Penelitian ini tidak hanya fokus pada analisis warna lokal dalam novel, tetapidilakukananalisis mengenai nilai-nilai positif yang ada di dalam novel Pasar karya 
Kuntowijoyo. Nilai-nilai positif tersebut mampu memberi sumbangsih terhadap wawasan pendidikan karakter peserta didik yang dilakukan melalui pembelajaran sastra.

\section{Metode}

Penelitian ini merupakan penelitian deskriptif kualitatif. Pendekatan yang digunakan ialah antropologi sastra. Pendekatantersebutmerupakanpendekatan yang digunakan untuk mempelajari sastra dan hubungannya dengan segala aspek kebudayaan yang ada di dalamnya. Pendekatan antropologi sastra dipilih karena sesuai dengan tujuan penelitian ini, yaitu mendeskripsikan warna lokal Jawa dalam novel karya Pasar karya Kuntowijoyo dan peran atau sumbangsihnya dalam pengembangan karakter peserta didik.

Sumber data penelitian ini ialah novel Pasar karya Kuntowijoyo. Novel ini dipilih sebagai subjek penelitian karena cerita di dalamnya mengekspresikan warna lokal budaya Jawa yang tidak hanya direpresentasikan oleh satu golongan saja, tetapi beberapa golongan masyarakat Jawa mulai dari priayi agraris, wong cilik, pegadang kapitalis, sampai birokrat. Novel tersebut juga banyak mengandung nilai positif yang akan berguna bagi pengembangan karakter peserta didik. Data penelitian ini berupa kata, kalimat, atau paragraf dalam novel Pasar karya Kuntowijoyo yang secara objektifkualitatif mengekspresikan warna lokal budaya Jawa.

Pengumpulan data menggunakan teknik baca catat yang dilakukan dengan membaca novel yang menjadi subjek penelitian dengan cermat, memberi tanda, dan mencatat data yang ditemukan. Teknik analisis data yang digunakan ialah teknik analisis isi (content analysis). Melalui teknik analisis tersebut, dapat dibuatsuatu kesimpulan yang valid dari subjek penelitian sesuai dengan konteks penggunaannya dan membantu peneliti menggali secara menyeluruh berbagai informasi yang terdapat dalam sebuah teks (Krippendorff: 2004, 18). Tahap kegiatan analisis data dimulai dengan memahami seluruh sumber data dan data penelitian. Data yang didapat dari sumber data penelitian kemudian diseleksi kembali (reduksi data). Tahap kedua, klasifikasi atau pengelompokan data-data berdasarkan butirbutir rumusan masalah. Tahap ketiga, penafsirandanpenjelasan data untuk menemukan kesatuan serta hubunganseluruh data penelitian, sehingga peneliti dapat mengambil kesimpulan yang valid.

\section{Hasil dan Pembahasan}

\subsection{Hasil}

Warna lokal Jawa dalam novel Pasar diklasifikasikan menjadi enam kategori. Berikut ini ialah tabel yang menunjukkan kategori warna lokal Jawa dalam novel Pasar karya Kuntowijoyo.

\section{Tabel 1}

Warna Lokal Jawa dalam Novel Pasar Karya Kuntowijoyo

\begin{tabular}{cll}
\hline No & \multicolumn{1}{c}{ Warna Lokal } & \multicolumn{1}{c}{ Halaman } \\
\hline 1 & Latar Tempat & $11-12,175,3-$ \\
& & 4 \\
2 & Sistem Religi atau & $352,176-177$, \\
& Kepercayaan & 2,8 \\
3 & Sistem & $1,9, \quad 160$ \\
& Kemasyarakatan dan & $191,82,190$, \\
& Organisasi Sosial & 87 \\
4 & Sistem Pengetahuan & $61,100,356$ \\
5 & Bahasa & $200,145,174$ \\
6 & Falsafah Jawa & 208,287 \\
\hline
\end{tabular}

\subsection{Pembahasan}

\subsubsection{Wujud Warna Lokal Novel Pasar Karya Kuntowijoyo}

\subsubsection{Latar Tempat}

Novel Pasar karya Kuntowijoyo memiliki latar tempat di Kecamatan Gemolong, salah satu kecamatan di Kabupaten Sragen, Jawa 
Tengah. Kutipan yang menunjukkan latar tempat yaitusebagaiberikut.

Sambil menunggu kedatangan Paijo untuk mencari jagung, beras, dan otek, Pak Mantri membuka tas mengeluarkan lembar koran. Koran itu dipinjamnya dari kantor kecamatan. Dan ketahuilah, hanya lingkungan terpelajar di Kecamatan Gemolong itu suka membaca koran. (Kuntowijoyo, 2017: 11-12)

Secara lebih terperinci, latar tempat dalam novel tersebut ialah Pasar Gemolong yang letaknya bersebelahan dengan Bank Pasar.

Dan papan itu berbunyi: "Pasar Gemolong."

Lho! Persis papan nama pasarnya. Hanya papan nama pasarnya sudah mengelupas catnya. (Kuntowijoyo, 2017: 175)

Tempat tersebut digambarkan sebagai pasar kecamatan yang ramai dengan pegadang dan calon penumpang yang menunggu bus datang. Keadaan Pasar Gemolong pada waktu itu digambarkan sebagai pasar yang tidak rapi dan tidak terawat.

Suatu daerah biasanya memiliki masyarakat dengan nama-nama yang khas dan membedakannya dengan masyarakat suku lain. Begitu pula dengan novel Pasar yang nama-nama tokohnya sangat mencerminkan masyarakat Jawa, seperti Paijo (tukang sapu pasar), Siti Zaitun (pegawai Bank Pasar), Kasan Ngali (pedagang kaya raya), dan Sri Hesti (pesinden). Latar tempat tersebut merupakan awal mula penggambaran warna lokal Jawa dalam novel Pasar. Berdasarkan latar tempat inilah, jalan cerita novel tersebut akan melukiskan warna lokal Jawa yang lain, seperti kebiasan, tradisi, kesenian, bahasa, dan lainnya.

\subsubsection{Sistem Religi atau Kepercayaan}

Religi merupakan suatu bentuk kepercayaan seseorang terhadap makhluk superior yang berkuasa di atas mereka (Lerner, 2006: 5).
Sistem religi tercipta karena adanya kepercayaan terhadap makhluk gaib yang dianggap lebih tinggi derajatnya, sehingga manusia berusaha menjalin komunikasi dan hubungan dengan kekuatan tersebut (Koentjaraningrat, 2009:294). Masyarakat Jawa dalam novel Pasar digambarkan sebagai masyarakat yang percaya terhadap adanya Tuhan.

\section{"Maka Pak Mantri jangan berhenti, Pak." \\ "Itu soal lain, Jo." \\ "Saya akan sendirian, Pak."}

"Tidak ada yang sendirian, Jo. Kalaupun itu terjadi, ingatlah selalu bahwa setidaknya Tuhan bersamamu." (Kuntowijoyo, 2017: 352)

Kutipan di atas merupakan percakapan yang terjadi saat Pak Mantri menyampaikan niatnya untuk pensiun menjadi mantri pasar. Paijo yang mendengar niat tersebut seketika memohon kepada Pak Mantri untuk mengurungkan niatnya karena Paijo tidak ingin bekerja sendiri di Kantor Pasar. Paijo sudah terbiasa bekerja menjadi bawahan Pak Mantri. Pak Mantri yang memiliki kepercayaan terhadap adanya Tuhan selalu menekankan kepada Paijo bahwa Tuhan akan selalu ada di sisi kita apa pun yang terjadi.

Menurut Stark dan Glock (dalam ElMenouar, 2014: 61), keyakinan seseorang terhadap Tuhan dibagi menjadi lima dimensi, yaitu (a) ideological dimension, yang menunjukkan keyakinan terhadap Tuhan, kitab suci, dan makhluk gaib seperti malaikat serta jin; (b) ritualistic dimension, kegiatan dalam merealisasikan keyakinannya, seperti sembahyang dan berdoa; (c) experience or experimental dimension, yang mengacu pada pengalaman ataupun perasaan keagamaan, seperti merasa dekat dengan Tuhan dan merasa bahwa doa yang ia panjatkan terkabul; (d) knowledge or intellectual dimension, berhubungan dengan pengetahuan mengenai keyakinannya; dan (e) consequences or secular consequences, yang menunjukkan keteguhan 
pada ajaran agamanya, seperti tidak berbohong dan selalu berbuat baik.

Kutipan di atas menyatakan bahwa Pak Mantri menunjukkan ideological dimension. Pak Mantri percaya dengan adanya Tuhan. Melalui perkataannya ia menyampaikan bahwa manusia sejatinya tidak pernah sendiri karena Tuhan akan selalu bersamanya. Selain itu, terdapat kutipan berikut.

"Dengar, Paijo. Kalau engkau kaya, jangan sekali-kali mengagungkan kekayaan.

Ketahuilah kekayaan itu tidak abadi. Sekarang engkau kaya, bisa saja besok pagi engkau miskin. Sekaya-kayanya orang di sini masih kaya Nabi Sulaiman. Harta itu titipan, nyawa itu pinjaman." (Kuntowijoyo, 2017: 176-177)

Kutipan tersebut merupakan nasihat Pak Mantri kepada Paijo untuk selalu rendah hati sebesar apa pun rezeki yang ia dapat. Nasihat Pak Mantri pada kutipan di atas menunjukkan dimensi religius berupa knowledge or intellectual dimension. Pengetahuan Pak Mantri terhadap ajaran agama Islam membawanya pada pengetahuan tentang kehidupan para Nabi yang penuh dengan hikmah kehidupan, salah satunya ialah Nabi Sulaiman yang memiliki rezeki berlimpah semasa hidupnya. Melalui nasihat tersebut, Pak Mantri berharap bahwa Paijo selalu bersyukur kepada Tuhan dan tetap rendah hati karena kekayaan dunia merupakan hal yang tidak abadi.

Koentjaraningrat

(2009:

menjelaskan bahwa dalam ilmu antropologi, sistem religi tidak dapat dipisahkan dengan sistem ilmu gaib. Dua hal tersebut sering dianggap sama, tetapi terdapat perbedaan paling mendasar di antara keduanya. Sistem religi berhubungan dengan sikap manusia yang berserah diri kepada Tuhan, dewa, atau kekuatan superior lain yang ia percayai. Berbeda halnya dengan sistem ilmu gaib yang menganggap kekuatan-kekuatan superior tersebut sebagai sesuatu yang digunaan untuk mendapatkan hal-hal yang ia inginkan.

Kedua kutipan di atas menggambarkan sistem religi berupa kepercayaan terhadap adanya Tuhan. Walaupun demikian, dalam novel Pasar juga terdapat kutipan yang mengekspresikan salah satu kebiasaan masyarakat Jawa yang sampai sekarang masih sering kita temukan.

Hari itu hari Pahing yang biasa, kalau mencari keramaian hari pasar, pada Kliwonlah. Namun, mereka pun tetap bersabar menunggu datangnya kesibukan. (Kuntowijoyo, 2017: 2)

Pak Mantri menghitung dengan jari, lalu mengangouk-angouk. Kemudian ia sadar, telah terpengaruh oleh tingkah para pedagang yang selalu menghitung hari-baik dan hariburuk. Semua hari itu sama saja, Pak Mantri. (Kuntowijoyo, 2017: 8)

Menghitung hari baik dan hari buruk merupakan hal yang wajar dalam budaya Jawa. Bukan hanya berdagang, tetapi juga dalam menentukan hari pernikahan, pindah rumah, sampai memulai usaha. Menurut (Purwadi dalamOktiasasi \& Harianto, 2016: 3)perhitungan Jawa (petungan Jawi) merupakan kegiatan menghitung baik dan buruk yang dilukiskan dalam lambang dan watak suatu tanggal, hari, bulan, tahun, pranata mangsa,serta wuku. Sebenarnya, kepercayaan ini tercipta dari pengalaman leluhur yang kemudian diingat, dicatat, dan dihimpun dalam sebuah primbon lalu diwariskan ke generasi selanjutnya. Walaupun sudah mengalami perubahan zaman, kebiasaan ini masih berlaku dibeberapa daerah Jawa Tengah.

Ketiga kutipan tersebut menjelaskan bahwa novel Pasar karya kuntowijoyo mampu menggambarkan warna lokal Jawa dalam sistem sistem religi atau kepercayaannya. Meskipun dalam novel 
tersebut diceritakan bahwa masyarakatnya memeluk agama Islam, tetapi beberapa di antaranya masih meyakini dan menjalankan tradisi lokal, seperti kutipan-kutipan di atas.

\subsubsection{Sistem Kemasyarakatan dan Organisasi Sosial}

Organisasi sosial merupakan sebuah perkumpulan atau komunitas yang terdiri atas beberapa individu yang saling berinteraksi untuk mencapai tujuan yang sama. Valeri (dalam Kurniawan \& Rudyansjah, 2016: 90)menjelaskan bahwa unsur budaya berupa sistem kemasyarakatan dan organisasi sosial meliputi perbedaan posisi berdasarkan gender, pimpinan dan bawahan, serta diferensiasi induvidu lainnya pada kelas sosial dalam kelompoknya.

Novel Pasar karya Kuntowijoyo mencerminkan sistem kemasyarakatan dan organisasi sosial berupa diferensiasi status sosial, yaitu priyayi agraris, wong cilik, birokrat, serta pedagang kapitalis. Golongan priyayi agraris diwakilkan oleh tokoh bernama Pak Mantri.

Kalau engkau terpelajar, dan tinggal di kecamatan itu, berhubunganlah dengan Pak Mantri Pasar. Sebab tidak seorang punkecuali Kasan Ngali, tentu-yang mengaku orang Jawa tidak memujinya. (Kuntowijoyo, 2017: 1)

Suroso (2011: 186)menjelaskan bahwa priyayi dibagi menjadi dua golongan, yaitu (a) priyayi pangreh praja, yang menjabat sebagai pemerintah daerah atau priyayi yang memiliki pangkat kebangsawanan; dan (b) priyayi yang terpelajar atau menjadi pegawai negeri karena pendidikan. Lain halnya dengan Kuntowijoyo (dalamUntoro, 2012: 84) yang membagi priyayi menjadi tiga golongan, yaitu (a) priyayi yang bekerja pada raja; (b) priyayi yang bekerja pada kerajaan; dan (c) priyayi yang terpelajar. Berdasarkan teori tersebut, Pak Mantri masuk ke dalam golongan priyayi terpelajar karena digambarkan sebagai sosok yang dihormati dan memiliki pengetahuan yang luas. Perhatikan kutipan berikut ini.

Pak Mantri melihat pula ketela itu, ia hanya menggeleng-geleng. Bila perut sudah berkasa, pikirnya. Pagi-pagi perut, siang perut, sore perut. Ah, orang itu kalau kurang pendidikan, tentu mementingkan perut lebih dari kewajiban. (Kuntowijoyo, 2017: 9)

Pada bagian awal cerita, seperti kutipan di atas, terlihat perbedaan sikap antara Pak Mantri dan Paijo. Pak Mantri menganggap bahwa saat kita memiliki suatu kewajiban, hendaknya kita selesaikan terlebih dahulu. Perbedaan sikap antara Pak Mantri dan Paijo disebabkan oleh perbedaan pendidikan yang mereka miliki.

Pak Mantri juga mampu mencerminkan sikap hidup masyarakat Jawa melalui nasihat serta pola pikirnya dalam menghadapi suatu masalah, seperti kutipan berikut.

"...Makna hidup itu tidak pada yang sekarang tetapi pada yang kemudian. Memang, mungkin sekarang kita susah. Itu hanya sementara. Kesusahan dan kesukaan lenyap dalam hidup kita. Keduanya adalah warna yang berlainan dari satu hal, yaitu hidup kita... Mengapa engkau khawatir? Kesusahan adalah karena pikiran kita sendiri...Mungkin sekarang engkau disusahkannya, tetapi kemudian, setelah alam jangka yang panjang, engkau tahu bahwa engkau sebenarnya berbahagia pada waktu dulu itu." (Kuntowijoyo, 2017: 160)

Masyarakat Jawa dikenal sebagai pribadi yang legowo atau menerima segala sesuatu dengan lapang dada dan nrimo ing pamdum atau menerima segala sesuatu tanpa menuntut lebih. Begitu pula dengan Pak Mantri yang selalu mengingatkan orang lain bahwa hidup haruslah legowo karena segala sesuatu yang terjadi di dunia adalah kehendak Tuhan. Sebagai manusia, kita harus mengerti bahwa hidup tidak selamanya berisi kegembiraan atau kesenangan tetapi juga 
kesukaran dan kesedihan. Kedua hal tersebut adalah satu kesatuan yang tidak dapat dipisahkan. Tugas utama sebagai manusia adalah berusaha dan berdoa. Apabila hasil yang didapat tidak sesuai dengan keinginan, maka jangan terlalu merasa susah dan sedih. Manusia harus bisa kenyataan tersebut lalu kembali berusaha. Saat kita telah mendapatkan segala sesuatu yang kita inginkan, maka masa-masa tersulit yang pernah kita lalui akan menjadi pembelajaran yang berharga dalam hidup.

Selanjutnya, golongan wong cilik pada novel Pasar digambarkan melalui tokoh Paijo. Paijo yang bekerja sebagai tukang sapu di lingkungan Pasar Gemolong tidak jarang mendapat perlakuan buruk dari orang di sekitarnya. Salah satunya adalah Kasan Ngali, seorang pedagang kapitalis yang tinggal di dekat Pasar Gemolong. Kutipan berikut menunjukkan perlakuan buruk Kasan Ngali kepada Paijo.

Apa hakmu mempermainkan orang, Kasan Ngali. Kalau aku buruhmu, bolehlah. Kalau aku makan gajimu, biarlah ... Mendapat marah dari Kasan Ngali menyakitkan hati, tetapi mendapat marah Pak Mantri bisa menyenangkannya. Sekalipun Pak Mantri sering memarahinya pula, bahkan mengancamnya akan mengeluarkan, dirasanya ia masih menghormati kepalanya itu. Kasan Ngali? Hhh! Tidak ada hak untuk menyakiti hati! Mentang-mentang kaya! Kehormatan itu tak bisa dibeli dengan uang, ketahuilah. Orang boleh berbeda dalam pangkat, kekayaan, umur, namun yang menentukan rendah-mulianya ialah budi. (Kuntowijoyo, 2017: 191)

Pendidikan Paijo yang terbilang cukup rendah dan posisi dalam pekerjaan sebagai tukang sapu,kerap kali menjadi alasan bagi orang lain melampiaskan kemarahan kepadanya. Kutipan di atas menceritakan kekesalan Paijo setelah berkunjung ke rumah Kasan Ngali. Menurut Paijo, Kasan
Ngali tidak memiliki hak untuk memarahinya karena yang menjabat sebagai atasannya adalah Pak Mantri, bukan Kasan Ngali. Walaupun Kasan Ngali merupakan orang yang cukup kaya dan terkenal di kecamatan itu, tidak berarti bahwa ia dapat berbuat semaunya dan menyakiti hati orang lain. Kekayaan dan status sosial menjadihal yang bersifat duniawi dan tidak dapat menentukan kemuliaan hati seseorang. Kutipan di atas menggambarkan bahwa wong cilik merupakan golongan yang tetap pantas untuk dihargai.

Status sosial Paijo sebagai wong cilik tidak bisa dilepaskan dari Pak Mantri yang berstatus sosial sebagai priyayi. Sikap Pak Mantri terhadap Paijo merupakan salah satu contoh baik dari golongan priyayi terhadap wong cilik. Meskipun Pak Mantri kerap memarahi Paijo karena beberapa pekerjaan yang tidak diselesaikan dengan baik, tetapi Pak Mantri tetap menghargai Paijo sebagai bawahan yang setia. Pak Mantri juga selalu menasihati Paijo tentang nilai-nilai kehidupan yang membuat Paijo merasa lebih nyaman bekerja dengannya. Penjelasan tersebut menunjukkan hubungan patron-klienatau atasbawah. Suhartono (dalam Untoro, 2012: 87) menjelaskan bahwa priyayi berada pada golongan atas, sedangan wong cilik berada pada golongan bawah. Pada hubungan patronklien, golongan patron menunjukkan pengayoman dan golongan klien menunjukkan pelayanan.

Golongan pegadang kapitalis diwakilkan oleh Kasan Ngali. Melalui penjelasan di atas dapat diketahui bahwa Kasan Ngali adalah seorang pedagang kaya yang terkenal di Kecamatan Gemolong. Langkah-langkah dalam mengembangkan usahanya sangat mencerminkan seorang pedagang yang hanya memikirkan keuntungan pribadi, seperti terlihat pada kutipan berikut.

Dapat dibayangkan, Kasan Ngali sedang sibuk menjuali gaplek. Orang kaya itu 
menimbun gaplek di musim panen, untuk dijual dengan harga tinggi di musim paceklik. Itulah yang didendamkan Pak Mantri atas nama perikemanusiaan. (Kuntowijoyo, 2017: 82)

Sikap Kasan Ngali dinilai sangat buruk oleh Pak Mantri. Tidak seharusnya orang kaya seperti Kasan Ngali berbuat kotor hanya untuk mendapatkan keuntungan dari pembeli. Tidak hanya itu, Kasan Ngali digambarkan sebagai seseorang yang selalu menyombongkan kekayaannya, sepeti yang terlihat pada kutipan berikut.

"Kasan Ngali bukan pengemis. Kasan Ngali orang kaya! lihatlah, karena itu saya sudah pasang papan nama segala. Apa boleh buat, karena engkau yang memulai. Engkau yang bertanggung jawab. Dan saya di panggil Pak Camat. Memalukan. Kurang uang apa saya, he! Tunjukkan siapa yang kaya di sini?"(Kuntowijoyo, 2017: 190)

Melalui kutipan tersebut Kuntowijoyo mencerminkan kehidupan orang kaya yang berbuat semena-mena terhadap sesama dan kerap melanggar peraturan yang ada. Kekayaan yang dimiliki Kasan Ngali membuat ia merasa bebas untuk melakukan apapun, termasuk mendirikan pasar baru demi menarik perhatian para pedagang dan mengalahkan Pak Mantri. Ketika perbuatannya diketahui oleh Pak Camat, Kasan Ngali melampiaskan amarahnya kepada Paijo dengan cara menyombongkan harta yang ia miliki.

Golongan yang terakhir adalah golongan birokrat yang diwakili oleh Pak Camat, pegawai kecamatan, dan Polisi. Melalui novel Pasar dapat diketahui bahwa dalam sebuah kelompok masyarakat, setiap organisasi termasuk organisasi pemerintahan memiliki tugas dan tujuan tersendiri, seperti kutipan berikut.

"Tetapi kami tak mengurusi pembunuhan burung. Perkara semacam itu tugas pamong praja. Pak Camat tentu bisa, Pak. Polisi hanya mengurus pembunuhan yang benarbenar pembunuhan, begitu." (Kuntowijoyo, 2017: 87)

Kutipan tersebut menceritakan Pak Mantri yang melapor pada polisi bahwa burung-burung dara yang ada di pasar telah dibunuh oleh para pedagang. Ketika polisi mendengar permasalahan tersebut, polisi lalu memberi penjelasan kepada Pak Mantri bahwa menangani hal tersebut bukan bagian dari tugasnya. Ada jabatan lain yang lebih tepat untuk menangani masalah tersebut. Namun, Pak Mantri berpendapat bahwa polisi bisa menangani masalah tersebut. Pak Mantri adalah rakyat yang membayar pajak, pajak digunakan untuk membayar gaji polisi, maka sudah sepantasnya polisi tersebut membantu menangkap para pedagang yang membunuh burung-burung daranya.

Keempat golongan yang diceritakan oleh Kuntowijoyo dalam novel Pasar merupakan sebuah warna lokal Jawa yang menggambarkan status sosial masyarakat Jawa. Sama halnya dengan masyarakat suku lain yang memiliki tingkat status sosial yang ditandai dengan nama marga, masyarakat Jawa juga dikenal dengan beberapa status sosial yang membedakan antara golongan satu dan yang lainnya.

\subsubsection{Sistem Pengetahuan}

Koentjaraningrat (2009: 289) menjelaskan bahwa setiap kelompok masyarakat memiliki sistem pengetahuan yang tercipta dari pengalaman kemudian menjadi sebuah konsep yang selalu mereka gunakan untuk bertahan hidup. Sistem pengetahuan masyarakat merujuk pada pengetahuan masyarakat dalam membuat suatu benda, karya, bangunan, bahkan membaca gejala alam. Salah satu warna lokal dalam novel Pasar karya Kuntowijoyo ialah sistem pengetahuan yang dimiliki oleh Pak Mantri.

Pak Mantri menulis di buku tamu. Dengan tulisan yang sempurna bagusnya. Dengan huruf Jawa yang berhias...Huh, kalau juru 
tulis itu bisa menandingi dia menulis huruf Jawa sebagus itu, baiklah ia kembali berguru. (Kuntowijoyo, 2017: 61)

Sebagai seorang priyayi yang dikenal pandai, Pak Mantri digambarkan memiliki pengetahuan dalam menulis dan membaca huruf Jawa. Tulisan Pak Mantri dianggap paling bagus bahkan jika dibandingkan dengan juru tulis kantor kecamatan. Hal tersebut diperkuat lagi pada kutipan berikut.

"Dengan huruf Jawa atau begini saja, Jo?"

"Mana ada orang ngerti huruf Jawa lagi?"

"Engkau betul."

Soal menulis huruf Jawa, di seluruh kecamatan tidak ada duanya. Guru-guru, pegawai pamong praja, bukan tandingan Pak Mantri. (Kuntowijoyo, 2017: 100)

Pada saat itu, kemampuan membaca dan menulis seseorang berhubungan dengan status sosialnya. Biasanya, golongan wong cilik tidak bisa mendapatkan pendidikan yang layak karena faktor ekonomi. Berbeda halnya dengan priyayi seperti Pak Mantri dan pejabat pemerintahan seperti Pak Camat serta pegawai kantor kecamatan lainnya. Sistem pengetahuan yang Pak Mantri miliki dapat ia gunakan untuk menulis surat, menulis laporan keuangan pasar, dan sebagainya. Melalui jawaban Paijo saat Pak Mantri bertanya,itumenandakan bahwa tidak semua masyarakat Kecamatan Gemolong bisa membaca huruf Jawa. Pak Mantri juga memiliki pengetahuan dalam merangkai tembang yang terlihat pada kutipan berikut.

"Hanya sedikit orang sekarang yang sanggup berbuat itu. Merangkai tembang.

Dengan bahasa Kawi. Bahasa para pujangga. Kepandaian ini hanya bagi orang Jawa." (Kuntowijoyo, 2017: 356)

Pengetahuan Pak Mantri tentang bahasa Kawi atau Jawa kuno membuatnya mahir dalam merangkai tembang yang indah. Kutipan di atas juga menjelaskan bahwa sesungguhnya pengetahuan lokal yang khas seperti menulis, membaca, dan merangkai tembang merupakan pengetahuan yang seharusnya dimiliki oleh setiap masyarakat Jawa. Namun, saat ini sudah banyak masyarakat Jawa yang melupakan bahasanya sendiri. Melalui kutipan-kutipan tersebut, dapat diketahui pula bahwa sistem pengetahuan masyarakat dalam novel Pasar karya Kuntowijoyo diwakilkan oleh pengetahuan yang dimiliki golongan priyayi dan para birokrat yang sudah pasti memiliki pendidikan dan golongan status sosial yang tinggi.

\subsubsection{Bahasa}

Bahasa merupakan unsur budaya yang mampu menjadi identitas suatu kelompok masyarakat karena dapat menjadi ciri khas dan membedakannya dengan masyarakat suku lain (Salzmann, dkk, 2012: 225). Warna lokal Jawa yang paling dominan pada novel Pasar karya Kuntowijoyo adalah bahasa Jawa yang digunakan dalam dialog antartokoh. Kuntowijoyo memperkuat nuansa lokal Jawa dengan menyisipkan kata-kata, kalimat, parikan (pantun Jawa), dan falsafah Jawa.

"Entah, Siti Zaitun menjerit, lalu Kasan Ngali kembali. Huh. Mana mau menerima. Ketheklek kayu mlandhingan. Sudah kakek, mau keranjingan! Tak tahu malu!"(Kuntowijoyo, 2017: 200)

Sama halnya dengan pantun Indonesia, parikan berisi sampiran dan isi yang memiliki hubungan bunyi. Parikan di atas merupakan jenis parikan lamba(terdiri dari dua baris) yang digunakan dalam dialog antara Paijo dan Pak Mantri. Paijo menceritakan usaha Kasan Ngali untuk mendapatkan hati Siti Zaitun, pegawai Bank Pasar, dengan membawa sebuah bungkusan sebagai hadiah. Saat menceritakan hal tersebut kepada Pak Mantri, Paijo menyisipkan sebuah parikan lamba"Ketheklek kayu mlandhingan. Sudah kakek, mau keranjingan!" untuk menyatakan ketidaksukaannya pada Kasan Ngali yang dianggapnya terlalu genit dengan wanita. 
Warna lokal Jawa dalam bentuk bahasa juga ditemukan pada novel Pasar dalam bentuk campur kode seperti kutipan-kutipan berikut.

"Orang itu kalau otaknya mandeg. Segalanya mesti di-nyunyuk-kan di matanya. Baru ia tahu. Baru ia sadar. Baru ia mengerti. Baru ia melek!" (Kuntowijoyo, 2017: 145)

Keunikan bahasa setiap daerah merupakanwarna lokal yang biasanya paling banyak ditemukan dalam karya sastra yang mengangkat unsur budaya sebagai keunikannya. Hal tersebut dapat berupa satu kalimat utuh dalam bahasa daerah, ataupun campur kode antara bahasa Indonesia dan bahasa daerah. Pada kutipan pertama, mandheg artinya berhenti, $d i$ nyunyuk-kanberarti diperlihatkan di depan mata, dan melek artinya membuka mata,dalam kalimat tersebut berarti sadar. Campur kode biasanya terjadi pada percakapan lisan seseorang yang menggunakan lebih dari satu bahasa. Percakapan dengan campur kode antara bahasa Indonesia dan bahasa daerah akan terjadi dengan baik apabila kominikator (penyampai pesan) dan komunikan (penerima pesan) memiliki latar belakang budaya dan daerah yang sama, sehingga istilah-istilah dalam bahasa daerah dapat dipahami dengan baik oleh keduanya.

\subsubsection{Falsafah Jawa}

Selain sastrawan, Kuntowijoyo juga dikenal sebagai sejarawan dan budayawan asli Jawa Tengah. Oleh karena itu, tidak diragukan bahwa karya-karya yang ia hasilkan mampu menggambarkan keadaan masyarakat Jawa secara realistis, salah satunya adalah falsafah Jawa yang digunakan masyarakat sebagai prinsip hidup, seperti kutipan-kutipan berikut.

"Jo, biarlah. Wani ngalah, duwur wekasane. Ingatlah itu. Sekarang kita kalah, belum berarti besok kita kalah juga. Sebab, salah seleh, siapa bersalah, akan menyerah kalah. Percayalah!" (Kuntowijoyo, 2017: 208)

Wani ngalah, duwur wekasane berarti seseorang yang berani untuk mengalah pada akhirnya akan mulia atau mendapat kemenangan di kemudian hari. Falsafah Jawa tersebut sering digunakan masyarakat Jawa sebagai prinsip hidup dalam menghindari perselisihan dan pertengkaran. Siswanto (2010: 208) menjelaskan bahwa salah satu prinsip hidup yang dimiliki masyarakat Jawa secara turun-temurun adalah menjaga keselarasan antara individu dengan Tuhan, keselarasan antarsesama, keselarasan antara individu dengan alam. Falsafah tersebut merupakan bukti prinsip hidup dalam menjaga keselarasan antarindividu agar tidak terjadi perselisihan, permusuhan, dan dapat hidup berdampingan dengan damai.Terdapat prinsip dasar yang dianut masyarakat Jawa dalam menjaga hubungan antarindividu, yaitu prinsip kerukunan dan prinsip penghormatan (Wibisono 2020: 33). Kedua prinsip tersebut dapat berwujud bahasa yang digunakan saat berbicara maupun cara bertindak seperti kutipan di atas. Falsafah yang kedua, yaitu sebagai berikut.

"Mengapa engkau menyusahkan diri dengan menyangkutkan pikiran pada perbuatan orang lain yang di luar dirimu? Berbuat baiklah. Dan selesai urusan. Becik ketitik ala ketara. Baik atau buruk akhirnya akan ketahuan juga, Ning. Bersabarlah." (Kuntowijoyo, 2017: 287)

Falsafah Jawa yang berbunyi becik ketitik ala kataradapat diartikan sebagai segala perbuatan manusia entah itu baik ataupun buruk, suatu saat akan terlihat. Pesan tersirat falsafah tersebut, yaitu sebaik-baiknya manusia adalah manusia yang selalu menolong sesama, hidup damai dengan orang lain, dan selalu berusaha untuk tidak melakukan hal-hal yang buruk karena suatu saat segala perbuatan akan mendapat balasannya. Apabila perbuatan baik dibalas 
dengan hal yang buruk oleh orang lain, handaknya kita bersabar. Hal tersebut berhubungan dengan prinsip hidup masyarakat Jawa, yaitu nrima. Sikap sabar dan nrima merupakansikap paling mulia bagi masyarakat Jawa (Hasim 2012: 310). Falsafah tersebut juga menyiratkan pesan bahwa Tuhan Maha Adil atas segala sesuatu di dunia ini. Becik ketitik ala ketara ialahfalsafah Jawa yang menyiratkan bahwa manusia harus bisa mengendalikan diri dari nafsu dan keinginan akan hal-hal yang negatif(Widyastuti 2012: 149-150).

\subsubsection{Warna Lokal Jawa Novel Pasarsebagai Sarana Pengembangan Karakter Peserta Didik}

Maraknya degradasi moral dan kekerasan yang terjadi, terutama dikalangan remaja, terjadi karena berbagai faktor. Salah satunya adalah karakter peserta didik yang dinilai kurang baik. Menurut Kanzunnudin (2012: 199)karakter merupakan perilaku manusia dalam wujud pikiran, perasaan, tindakan, dan perkataan yang berhubungan dengan Tuhan, diri sendiri, sesama manusa, serta lingkungan. Permasalahan tersebut menjadi alasan utama adanya pendidikan karakter yang saat ini sedang gencar dilakukan.

Pendidikan karakter dapat juga dikatakan sebagai pendidikan budi pekerti atau pendidikan moral karena diartikan sebagai proses membentuk budi pekerti, moral, dan akhlak peserta didik (Sabakti 2018: 190). Selain keluarga, guru dan lingkungan sekolah diharapkan mampu mengembangkan karakter peserta didik menjadi lebih baik sehingga masalah tersebut dapat teratasi.

Sastra dapat menjadi salah satu sarana untuk mengembangkan karakter peserta didik. Sebuah karya sastra, termasuk novel, memiliki fungsi dulce et utile yang berarti menghibur sekaligus bermanfaat. Sastra menghibur dengan keindahannya dan sastra bermanfaat sebagai sarana penyampai nilainilai kebaikan. Sastra mampu membenahi perilaku menyimpang karena mengandung norma dan nilai positif yang dapat dicontoh (Eagleton, 1996: 4). Pelaksanaan pendidikan karakter tidak dilakukan dengan menciptakan mata pelajaran tersendiri, tetapi dilakukan dengan mengaitkan atau menghubungkan mata pelajaran yang sudah ada dengan nilainilai pendidikan karakter. Oleh karena itu, guru memiliki andil besar dalam hal ini.

Pemilihan bahan ajar yang tepat akan sangat membantu dalam pengembangan karakter peserta didik, salah satunya adalah novel yang mengangkat warna lokal sebagai ciri khasnya. Melalui novel yang menceritakan kehidupan suatu kelompok masyarakat lengkap dengan budayanya, peserta didik diharapkan tidak hanya mendapat pengetahuan berupa teori sastra, tetapi juga pengetahuan budaya dan nilainilai positif yang dapat di dalamnya.

Pendidikan karakter melalui penanaman pengetahuan budaya dan nilai positif di dalamnya sejalan dengan kategori pengelompokkan pendidikan karakter menurut Kanzunnudin (2012: 201). Pendidikan karakter dikategorikan menjadi empat, yaitu (a) pendidikan karakter berbasis nilai religius (konservasi moral); (b) pendidikan karakter berbasis nilai budaya (konservasi budaya), seperti budi pekerti, apresiasi sastra, dan keteladanan tokoh sejarah; (c) pendidikan karakter berbasis lingkungan (konservasi lingkungan); serta (d) pendidikan karakter berbasis potensi diri (konservasi humanis). Berdasarkan kategori tersebut, warna lokal dalam novel yang digunakan sebagai bahan ajar akan mendorong terjadinya pendidikan karakter berbasis nilai budaya (konservasi budaya).

Salah satu novel yang dapat digunakan ialah novel Pasar karya Kuntowijoyo. Melalui novel tersebut, Kuntowijoyo menceritakan kehidupan sosial dan budaya masyarakat 
Kecamatan Gemolong, Jawa Tengah. Tokoh utama dalam novel tersebut bernama Pak Mantri, seorang priyayi yang terpelajar dan sangat mencerminkan sikap orang Jawa. Selain tokoh priyayi, ada juga tokoh yang mencerminkan golongan wong cilik seperti Paijo, pedagang kapitalis yang bernama Kasan Ngali, dan birokrat yang diwakilkan oleh Pak Camat dan bawahannya. Cerita yang disampaikan tidak hanya berisi konflik sosial antarmasyarakat, tetapi juga adat istiadat dan prinsip hidup yang saat itu masih dipegang teguh oleh setiap tokoh. Tokoh-tokoh yang ada dalam novel Pasar mencerminkan golongan status sosial masyarakat Jawa, sedangkan adat istiadat dan prinsip hidup tokoh menggambarkan unsur budaya yang ada di dalamnya.

Banyaknya pengetahuan budaya dan nilai positif dalam novel tersebut diharapkan mampu menjadi faktor pendorong berhasilnya pengembangan pendidikan karakter peserta didik melalui pembelajaran sastra. Peserta didik yang berhasil menikmati dan memahami karya sastra akan meningkatkan rasa apresiasi sastra dalam dirinya. Peserta didik akan memahami bahwa sastra bukan hanya sekadar karya imajinasi pengarang, tetapi juga gambaran sosial yang memiliki berbagai pesan positif yang berguna bagi dirinya.

\section{Simpulan}

Terciptanya novel yang mengangkat warna lokal suatu daerah dipicu oleh pengarang yang tidak dapat memisahkan diri dari budaya yang sudah melekat pada dirinya. Salah satu contohnya ialahnovel Pasar karya Kuntowijoyo. Berdasarkan penelitian terhadap warna lokal Jawa dalam novel Pasar karya Kuntowijoyo dan sumbangsihnya terhadap pengembangan pendidikan karakter peserta didik, dapat disimpulkan bahwa novel tersebut mengandung beberapa warna lokal Jawa, seperti (a) latar tempat di Kecamatan Gemolong; (b) sistem religi yang mempercayai adanya Tuhan, tetapi tetap mempertahankan budaya religinya; (c) sistem kemasyarakatan dan organisasi sosial yang menggambarkan empat golongan status sosial masyarakat Jawa (priyayi, wong cilik, pedagang kapitalis, dan birokrat); (d) sistem pengetahuan tokoh priyayi Jawa; (e) bahasa; serta (f) falsafah Jawa yang digunakan sebagai prinsip hidup masyarakat.

Keenam warna lokal Jawa dalam novel Pasar membuktikan bahwa novel tersebut kaya akan gambaran budaya yang dapat menambah pengetahuan budaya dan nilainilai positif yang beguna bagi kehidupan peserta didiksehingga mampu membantu peserta didik untuk mengembangan karakternya. Oleh karena itu, novel yang mengangkat warna lokal suatu daerah memiliki sumbangsih besar dalam pengembangan karakter peserta didik melalui pembelajaran sastra.

\section{Daftar Pustaka}

Agustin, D. S. Y. 2011. "Penurunan Rasa Cinta Budaya dan Nasionalisme Generasi Muda Akibat Globalisasi." Sosial Humaniora 4(2):177-85. https:/ / doi.org/10.12962/j24433527.v4 i2.632

Annisa, A. I., \& Indiatmoko, B. 2017. "Representasi Sistem Penikahan Budaya Yogya dalam Novel "Perempuan Jogja Karya Achmad Munif." Seloka 6(1):74-84.

El-Menouar, Y. 2014. “The Five Dimensions of Muslim Religiousity: Result of an Empirical Study." Methods, Data, Analyses 8(1):53-78.

Hartono. 2015. “Warna Lokal Jawa dalam Novel Indonesia Periode 1980-1995." 
Litera 14(2):392-403.

https:/ / doi.org/10.21831/1tr.v14i2.72 12

Hasim, M. 2012. “Falsafah Hidup Jawa dalam Naskah Sanguloro." Lektur Keagamaan 10(2):301-20.

Hikmasari, M., \& Sahayu, W. 2019. "Unsur Budaya Material dalam Novel 'Entrok' Karya Okky Madasari." Atavisme 22(2):200-216. https:/ / doi.org/10.24257/atavisme.v 22i2.586.200-216

Kanzunnudin, M. 2012. "Peran Sastra dalam Pendidikan Karakter." hlm. 195-204 in Prosiding Seminar Nasional Pendidikan: Pendidikan untuk Kejayaan Bangsa.

Kurniawan, A. \& Rudyansjah, T. 2016. "Kajian Mengenai Perubahan Afiliasi pada Sistem Organisasi Sosial Masyarakat Lematang." Jurnal Antropologi: Isu-Isu Sosial Budaya 18(2):89-103.

https:// doi.org/10.25077/jantro.v18i 2.60

Oktiasasi, A. W., \& Harianto, S. 2016. "Perhitungan Hari Baik dalam Pernikahan." Paradigma 4(3):1-10.

Ratna, I. N. K. 2011. “Antropologi Sastra: Perkenalan Awal." Metasastra 4(2):150-59.

Sabakti, S. 2018. “Konsep Pendidikan Karakter dalam Buku 'Pandangan Orang Melayu terhadap Anak' Karya Tenas Effendy." Widyaparwa 46(2):189-204.

https:// doi.org/10.26499/wdprw.v4 $6 i 2.193$
Sebo, L., Andayani., \& Subiyantoro, S. 2017.

"Nilai Pendidikan Karakter dan Kearifan Lokal Legenda Wae Reke Masyarakat Ngada, Nusa Tenggara Timur dalam Relevansinya dengan Pembelajaran Sastra Tingkat SLTP." Aksara 2(1):32-45.

Siswanto, D. 2010. “Pengaruh Pandangan Hidup Masyarakat Jawa terhadap Model Kepemimpian (Tinjauan Filsafat Sosial)." Jurnal Filsafat 20(3):197-216.

Suroso. 2011. “Kepriyayian Tokoh dalam Novel Warna Lokal Jawa dan Sumbangsihnya dalam Pengembangan Karakter Bangsa." Litera 10(2):183-91. https:/ / doi.org/10.21831/ltr.v10i2.116 2

Triyanto. 2014. "Pendidikan Seni Berbasis Budaya." Imajinasi: Jurnal Seni 7(1):3342.

Untoro, R. 2012. "Priyayi Dan Kawula dalam Pasar Karya Kuntowijoyo." Metasastra 5(1):83-91.

https://doi.org/10.26610/metasastra.2 012.v5i1.83-91

Wibisono, S. 2020. “Teknik dan Strategi Penciptaan Humor Komedian Jawa dalam 'Basiyo-Nartosabdho Besanan.'" Widyaparwa 48(1):28-40.

https:/ / doi.org/10.26499/wdprw.v48i 1.509

Widyastuti, S. H. 2012. "Kandungan Nilai Moral dalam Ungkapan Tradisional Jawa dan Pepatah Cina." Litera 11(1):147-57.

https:/ / doi.org/10.21831/ltr.v11i1.115 4 